\title{
CLINICAL, PARASITOLOGICAL AND OBSTETRIC OBSERVATIONS IN PREGNANT BITCHES WITH EXPERIMENTAL TOXOPLASMOSIS
}

\author{
TOXOPLASMOSE EXPERIMENTAL EM CADELAS GESTANTES - OBSERVAÇÕES \\ CLIINICAS, PARASITOLÓGICAS E OBSTÉTRICAS
}

\author{
Katia Denise Saraiva Bresciani ${ }^{1}$ Gilson Hélio Toniollo ${ }^{2}$ Alvimar José da Costa ${ }^{3}$ \\ Gustavo Adolfo Sabatini ${ }^{4}$ Flávio Ruas de Moraes ${ }^{5}$
}

\section{SUMMARY}

Eight pregnant mixed breed bitches, serologically negative for Toxoplasma gondii, were divided into three groups. Group I : bitches 01 and $02\left(1.0 \times 10^{7}\right.$ tachyzoites of Toxoplasma gondii, subcutaneous route); Group II: bitches 03, 04 and 05 (1.5 $x 10^{4}$ oocysts, oral route); Group III: bitches 06, 07 and 08 (as control). Clinical and obstetric examinations were conducted twice a day on each bitch, and weekly ultra-sonografic evaluations were performed until the end of pregnancy. From the $2^{\text {nd }}$ day the bitches presented clinical alterations such as fever, nasal flowing, lachrymation, prostration, lymphadenopathy, premature parturition, abortion and fetal death. In Group I, Toxoplasma gondii was isolated from the bitches urine (day 10) and saliva (day 18). The bitches inoculated with oocysts showed milk samples collected on day 07 and day 16 after inoculation positive for Toxoplasma gondii. Saliva collected on day 13 and urine samples collected on days 1, 3, 7 and 16 from these bitches also showed positive. All inoculated bitches reacted positively to antigenic stimulus, with production of Toxoplasma gondii antibodies from day 3 on, with highest titers detected on day 11 . Antibodies were detected by Indirect fluorescent antibody test (IFAT) and Enzyme linked immunosorbent assay (ELISA) tests.

Key words: toxoplasmosis, Toxoplasma gondii; pregnant bitches, pathology.

RESUMO

Oito cadelas gestantes, sem raça definida, clínica e sorologicamente negativas para Toxoplasma gondii, foram distribuídas em três grupos, de acordo com o inóculo: Grupo Icadelas 01 e 02 (1 $\times 10^{7}$ taquizoítos, por via subcutânea); Grupo II - cadelas 03, 04 e $05\left(1,5 \times 10^{4}\right.$ oocistos esporulados de Toxoplasma gondii, por via oral) e Grupo III - cadelas 06, 07 e 08 (controle/placebo). Monitoramento clínico e obstétrico diários e acompanhamento ultra-sonográfico semanal foram realizados até o final da gestação. Os principais sinais clínicos evidenciados a partir do $2^{\underline{0}}$ dia pós-inoculação (DPI) foram: febre, corrimento nasal, lacrimejamento, prostração, linfoadenopatia, parto prematuro, abortamento e morte fetal. No Grupo I, Toxoplasma gondii, foi isolado da urina no $10^{\circ}$ dia e da saliva no $18^{\circ}$ dia. As amostras de leite colhidas de cadelas infectadas com oocistos (Grupo II), foram positivas para a presença do parasito no $7^{0} e$ $16^{o}$ DPI. No Grupo II, Toxoplasma gondii também foi isolado de amostras de urina colhidas nos dias 01,03,07 e 16 DPI e na saliva no dia 13 DPI. Todas as cadelas reagiram positivamente ao estímulo antigênico, produzindo anticorpos anti- Toxoplasma gondii, através do teste de Imunofluorescência indireta (IFI) e ensaio imunoenzimático indireto (ELISA), a partir do $3^{-}$DPI, alcançando títulos máximos no $11^{\circ}$ dia pós- inoculação.

Palavras-chave: toxoplasmose; Toxoplasma gondii; cadelas gestantes; patologia.

\section{INTRODUCTION}

In the last decade, toxoplasmosis in dogs has been detected in many countries (DUBEY \&

\footnotetext{
${ }^{1}$ DVM, Assistant Professor, Mestre, Departamento de Apoio, Produção e Saúde Animal, FOA/ Universidade Estadual Paulista (UNESP), Araçatuba, São Paulo, Brazil. Av. Clóvis Pestana, 793, 16050-680. E-mail: katia @ fmva.unesp.br. Autor para correspondência.

${ }^{2}$ DVM, Professor, PhD., Departamento de Medicina Veterinária Preventiva e Reprodução Animal, Faculdade de Ciências Agrárias e Veterinárias Jaboticabal (FCAVJ),UNESP, Jaboticabal, São Paulo, Brazil.

${ }^{3}$ DVM, Professor, PhD., Centro de Pesquisas em Sanidade Animal/CPPAR/ FCAVJ-UNESP, Jaboticabal, São Paulo, Brazil.

${ }^{4}$ DVM, Mestre, CPPAR/ FCAVJ-UNESP, Jaboticabal, São Paulo, Brazil.

${ }^{5}$ DVM, Professor, PhD., Centro de Pesquisas em Sanidade Animal/CPPAR/ FCAVJ-UNESP, Jaboticabal, São Paulo, Brazil.
} 
BEATTLE, 1988; LINDSAY et al., 1990; GUIMARÃES et $\boldsymbol{a l} ., \quad$ 1992). Concerning epidemiological, parasitological and clinical aspects of this infection, clinical alterations such as hypothermia, lymphadenopathy, respiratory and digestive disorders were described in dogs experimentally infected with Toxoplasma gondii by OPPERMAN (1971) and SHARMA et al. (1973).

Natural toxoplasmosis was showed in a Fox Hound dog in Jaboticabal , S.P. Brazil (COSTA et al., 1978) during which clinical, serological, histopathological and parasitological alterations were observed.

Congenital Toxoplasma gondii infection has been reported, but no case has been well documented in dogs, reviewed by DUBEY (1985), DUBEY \& BEATTLE, 1988). BRESCIANI et al. (1999), first showed that dogs could be congenitally infected with Toxoplasma gondii after oral inoculation of bitches with oocysts. The main purpose of this study was to collect more information on toxoplasmosis in pregnant bitches since current information on the subject was sparse.

\section{MATERIAL AND METHODS}

A inoculum of Toxoplasma gondii, $\mathrm{P}$ strain, maintained at the "Center of Research in Small Animal Health"- CPPAR/UNESP, was employed. Identification of sporulated forms was made using morphological criteria (ZAMAN, 1970) and intraperitoneal inoculation in mice, according to DUBEY et al. (1972).

Eight mixed breed pregnant bitches were used, all serologically negative for Toxoplasma gondi. Three of these were kept as controls inoculated with a placebo. In order to confirm pregnancy, an ultra-sonography apparatus was used (Kontron Sigma 21 transductor wobbler $7.5 \mathrm{mhz}$ and linear transductor $5 \mathrm{mhz}$ ). Bitches were kept in individual cages, with free access to comercial dog food and water. Clinical and laboratorial testings were done for blood, feces and urine samples, for assessment of overall good health of animals. Before inoculation bitches were distributed as shown in table 1 .

Complete clinical examinations were conducted on each dog twice a day, in the morning and afternoon up, until end of the pregnancy. Weekly ultra-sonography evaluations were performed.

Hematological examinations were performed as recommended by SCHALM $\boldsymbol{e t} \boldsymbol{a l}$. (1986). Determinations of alanine amine transferase (ALT), aspartate amine transferase (AST), lactic
Table 1 - Experimental inoculation of Toxoplasma gondii in pregnant bitches : bitches 01 and 02, subcutaneously inoculated with tachyzoites; bitches 03,04 and 05 inoculated orally with oocysts; and bitches 06, 07 and 08 given placebo subcutaneously and orally (control group).

\begin{tabular}{|c|c|c|c|c|c|}
\hline \multirow[t]{3}{*}{ Groups } & Number & Stage of & \multicolumn{3}{|c|}{ Toxoplasma gondii inoculum } \\
\hline & of & pregnancy & Evolutive & Quantitity & Route \\
\hline & bitch & (days) & Form & & \\
\hline \multirow[t]{2}{*}{ I } & 1 & 52 & Tachyzoites & $1.0 \times 10^{7}$ & Subcutaneous \\
\hline & 2 & 40 & Tachyzoites & $1.0 \times 10^{7}$ & Subcutaneous \\
\hline \multirow{3}{*}{ II } & 3 & 56 & Oocysts & $1.5 \times 10^{4}$ & Oral \\
\hline & 4 & 40 & Oocysts & $1.5 \times 10^{4}$ & Oral \\
\hline & 5 & 32 & Oocysts & $1.5 \times 10^{4}$ & Oral \\
\hline \multirow{3}{*}{ III } & 6 & 52 & Saline & Control & Subcutaneous \\
\hline & 7 & 55 & Saline & Control & Oral \\
\hline & 8 & 51 & Saline & Control & Oral \\
\hline
\end{tabular}

dehydrogenase (LDH), creatinine phosphokinase (CPK), alcaline phosphatase, albumine, total proteins, glucose, direct and indirect bilirubin, amylase and lipase in biochemical analysis of blood serum, according to customary techniques (KANEKO \& CORNELIUS, 1989), using photometric readings (COLLEMAN 295 - CELM São Paulo, SP) were assessed, every week, for all dogs until the end of the experiment.

Urine samples were collected from the bitches one week before inoculation, and at seven day intervals after inoculations until the end of the experimental period. Attempts with the same periodicity at the exams urine, were collected for the parasite isolation.

Urine, saliva and milk samples were taken from each pregnant bitch (VITOR \& PINTO, 1991) and inoculated by the peritoneal route in groups of three albino mice, weighing 18 to 25 grams, both sexes being represented. After 6 weeeks the surviving mice were bled for the obtention of sera in which anti Toxoplasma gondii antibodies were searched by IFAT (CAMARGO, 1964) and the mice encephales were examinated for the eventual presence of cysts.

Saliva samples were taken immediately before death through endovenous administration of a pilocarpine solution. Toxoplasma gondii isolation from milk, was attemped mostly in the posparturition, after giving each bitch oxytocin endovenously (VITOR \& PINTO, 1991). All bitches were euthanasied immediately after parturition, through painless process (thiopental sodic + potassium chloride). 
In the sera collected daily during the first fortnight and at every three days until euthanasia, screening for Toxoplasma gondii antibodies was done using an indirect immunofluorescence test (IIFAT), as described by CAMARGO (1964) and a enzyme linked immunosorbent assay test (ELISA), as used by DOMINGUES et al. (1998).

The soluble antigen was prepared from purified parasite suspension. The protein concentration was determined by the method of HARTREE (1972). The IFAT a FITC labelled rabbit anti-dog IgG (SIGMA IMMUNO CHEMICALS) diluted 1/100 and ELISA tested a alcaline phosphatase conjugated polyclonal rabbit anti-dog (SIGMA IMMUNO CHEMICALS) diluted $1 / 200$, were used a secondary antibodies were used, respectively.

On the day of birth blood samples were taken from all pups born alive and screenied for presence of Toxoplasma gondii antibodies (IFAT and ELISA).

\section{RESULTS AND DISCUSSION}

Two days after inoculation all bitches showed alteration at clinical signs (Table 2) consisting mainly of fever, increase in respiratory resonance, respiratory stertors, nasal flowing, eye secretion and lymphadenopathy. These were similar to findings of OPPERMAN (1971), SHARMA et al. (1973) and COSTA et al. (1977; 1978). In opposition to the observations made by AVERIL \& de LAHUNTA (1971), NESBIT $\boldsymbol{e t}$ al. (1981) and SUTER $\boldsymbol{e t}$ al. (1984) no neurologic abnormalities were observed in the infected bitches. The non appearance of nervous manifestations inoculated bitches may be due to the limited period of observation.

Lymphadenopathy was frequent in infected bitches. All of those infected with oocysts presented hyperthermia. Clinical signs presented were similar to those described by VIDOTTO \& COSTA (1987) in infected pregnant sows. The reproductive disorders observed on inoculated bitches were abortion, fetal death and premature parturition (Table 3 ).

The decrease in number of red blood cells, of hemoglobin content and in hematocrit values may possibly be attributed to an immunitary response. Responses to inoculation according type of inoculum used. Due to this variation, the determination of leucocytary response was not made possible.

All bitches infected with Toxoplasma gondii showed a increase of AST, direct and indirect bilirubin and ALT levels, beside hypoalbunemia. All these signs indicated a possible pathology of the liver (DUNCAN \& PRASSE, 1982). The determinations of lactic dehydrogenase $(\mathrm{LDH})$, creatinine phosphokinase (CPK), alcaline phosphatase, albumine, total proteins, glucose, direct and indirect bilirubin, amylase and lipase didn't demonstrate alterations.

Concerning the milk samples, Toxoplasma gondii could be detected only in those collected from bitches inoculated with oocysts (Table 4). The isolation of Toxoplasma gondii from urine and saliva (Table 4), similarly to that was observed in goats by VITOR \& PINTO (1991), emphasizes the possible importance of those organic liquids on the dissemination of zoonosis. Presence of tachyzoites in urine, saliva or milk was shown only in the acute stage of infection. The largest period of observation was 16 days. Since the dogs were euthanasied immediately after parturition, it was not possible to collect samples from chronic phase of infection that would occur afterwards.

All the infected
bitches reacted to the

Table 2 - Clinical signs in pregnant bitches either from the control group $(6,7$ and 8 ) or inoculated subcutaneously with Toxoplasma gondii tachyzoites (1 and 2) or orally with Toxoplasma gondii oocysts (3, 4 and 5).

\begin{tabular}{cccccccccc}
\hline $\begin{array}{c}\text { Bitch } \\
\mathrm{N}^{\mathrm{o}}\end{array}$ & $\mathrm{H}^{1}$ & $\mathrm{Tc}^{2}$ & $\mathrm{Tp}^{3}$ & $\mathrm{IRR}^{4}$ & $\mathrm{PS}^{5}$ & $\mathrm{~A}^{6}$ & $\mathrm{Ap}^{7}$ & $\mathrm{ONS}^{8}$ & $\mathrm{~L}^{9}$ \\
\hline 01 & $+(2-3)$ & $+(3)$ & $+(3)$ & $+(3)$ & - & - & - & $+(2-3)$ & $+(2-3)$ \\
02 & - & - & $+(6-7)$ & $+(1-7)$ & $+(8-18)$ & - & - & $+(2-18)$ & $+++(1-18)$ \\
03 & $+(6-7)$ & - & $+(6-7)$ & $+(6-7)$ & - & - & - & $+(2-7)$ & $+(1-7)$ \\
04 & $+(11-12)$ & $+(9-10)$ & $+(2-6)$ & $+(6-16)$ & $+(6-16)$ & $+(9-10)$ & $+(6-10)$ & $+(3-16)$ & $++(6-16)$ \\
05 & $+(2-3)$ & - & - & - & - & - & - & & $++(2-7)$ \\
$06^{\mathrm{t}}$ & - & - & - & - & - & - & - & - & - \\
$07^{\mathrm{t}}$ & - & - & - & - & - & - & - & - & - \\
$08^{\mathrm{t}}$ & - & - & - & - & - & - & - & - & - \\
\hline
\end{tabular}

${ }^{1}:$ H=Hyperthermia; ${ }^{2}: \mathrm{Tc}=$ Tachycardia; ${ }^{3}: \mathrm{Tp}=$ Tachypnea; ${ }^{4}: \mathrm{IRR}=$ Increase respiratory resonance;

${ }^{5}: \mathrm{PS}=\mathrm{Pulmonary}$ stertors; ${ }^{6}: \mathrm{A}=$ anorexia; ${ }^{7}: \mathrm{AP}=$ apathy; ${ }^{8}: \mathrm{ONS}=\mathrm{Ocular}$ and nasal secrection;

${ }^{9}:$ L=Lymphadenopathy; $+=$ clinical alterations; $($ )=day after inoculation antigenic stimuli at inoculation with production of Toxoplasma gondii antibodies after 3 days and the highest titer values occured about day 15. These results are in accordance to those found by VIDOTTO \& COSTA, (1987). It is interesting to mention that one of the main clinical signs observed lymphadenopathy - coincided with the beginning of the humoral response. Serological titers obtained by IFAT and ELISA were in accordance. 
Table 3 - Obstetric signs in pregnant bitches either from the control group (6, 7 and 8) or inoculated subcutaneously with Toxoplasma gondii tachyzoites (1 and 2) or orally with Toxoplasma gondii oocysts (3, 4 and 5).

\begin{tabular}{ccccc}
\hline $\begin{array}{c}\text { Bitch } \\
\text { Number }\end{array}$ & $\begin{array}{c}\text { Premature } \\
\text { birth }\end{array}$ & Abortion & $\begin{array}{c}\text { Fetal } \\
\text { death }\end{array}$ & $\begin{array}{c}\text { Normal } \\
\text { parturition }\end{array}$ \\
\hline 01 & $(3)^{*}$ & - & - & - \\
02 & - & - & $(18)^{*}$ & - \\
03 & - & - & - & $(7)^{*}$ \\
04 & - & - & $(16)^{*}$ & - \\
05 & - & $(7)^{*}$ & - & - \\
06 & - & - & - & $(10)^{*}$ \\
07 & - & - & - & $(7)^{*}$ \\
08 & - & - & - & $(14)^{*}$ \\
\hline
\end{tabular}

* Day of necropsy

( ) Day after inoculation

Among the bitches that received tachyzoites and aborted, the highest titer observed was 1:256 (IFAT) and level 05 (ELISA). Those of Group II, inoculated with oocysts, and newborn pups alive from Groups I and II, showed a serological peak of 1: 1024 and level 04, for IFAT and ELISA, respectively. The differences in the inocula (type, dosage and route of administration) may perhaps justify this immunitary discrepancy. Therefore, these results confirm high sensibility on the pregnant bitches to the oocysts of Toxoplasma gondii as well as their importance in public health.

Table 4 - Results of screening for Toxoplasma gondii in milk, saliva and urina of pregnant bitches either from the control group $(6,7$ and 8$)$ or inoculated subcutaneously with tachyzoites (1 and 2$)$ or orally with oocysts (3, 4 and 5) in days after inoculation .

\begin{tabular}{ccccccccc}
\hline Bitch N $^{\mathbf{0}}$ & \multicolumn{7}{c}{ Days after inoculation } \\
\cline { 2 - 8 } & 01 & 03 & 07 & 10 & 13 & 15 & 16 & 18 \\
\hline 01 & & $*$ & & & & & & \\
02 & & & & $\mathrm{U}$ & & & $\mathrm{S}^{*}$ \\
03 & $\mathrm{U}$ & & $\mathrm{M}^{*}$ & & & & & \\
04 & & $\mathrm{U}$ & & & $\mathrm{S}$ & & $\mathrm{MU}^{*}$ & \\
05 & & & $\mathrm{MU}^{*}$ & & & & & \\
06 & & & & $*$ & & & & \\
07 & & & $*$ & & & & \\
08 & & & & & $*$ &
\end{tabular}

* Day of necropsy

* Day before necropsy

M - Presence of Toxoplasma gondii antibodies (IIF, 1: 64) in inoculated mice with milk pregnant bitches.

U - Presence of Toxoplasma gondii antibodies (IIF, 1: 64) in inoculated mice with urina pregnant bitches.

S - Presence of Toxoplasma gondii antibodies (IIF, 1: 64) in inoculated mice with saliva pregnant bitches.

\section{ACKNOWLEDGEMENTS}

We wish to thank Fortunato Alexandre Ferreira and Eugênio de Campos Filho for excellent technical assistance. Financial support was provided by CAPES and FAPESP through CPPAR.

\section{REFERENCES}

AVERILL, D.R., de LAHUNTA, A. Toxoplasmosis of the canine nervous system: Clinicopathological findings in four cases. Journal American Veterinary Medical Association. v.159, p.1134-1141, 1971.

BRESCIANI, K.D.S., COSTA, A.J., TONIOLlO, G.H., et al. Experimental toxoplasmosis in pregnant bitches. Veterinary Parasitology, v.86, p.143-145, 1999.

CAMARGO, M.E. Improved technique of indirect immunofluorescence for serological diagnosis of toxoplasmosis. Revista do Instituto de Medicina Tropical, São Paulo, v.6, n.3, p.117-118, 1964.

COSTA, A.J., ARAÚJO, F.G., COSTA, J.O., et al. Experimental infection of bovines with oocysts of Toxoplasma gondii. Jounal Parasitology, v.63, n.2, p. 212-218, 1977.

COSTA, A.J., LUCAS, A., MORAES, F.R., et al. Contribuição ao estudo da toxoplasmose canina. O Biológico, v.XLIV, p.293-297, 1978.

DOMINGUES, L.M., MACHADO, R.Z., COSTA, M.T. et al. Canine toxoplasmosis: a comparative evaluation of the detection of anti- Toxoplasma gondii antibodies by the indirect immunoenzymatic assay (ELISA) and the indirect immunofluorescence reaction (IIF). Revista Brasileira de Parasitologia Veterinária, v.7, n.2, 79-85, 1998.

DUBEY, J.P., SWAN, G.V., FRENKEL, J.K.A. Simplified method for isolation of Toxoplasma gondii from the feces of cats. Journal Parasitology, v.58, n.5, p.1055-1056, 1972.

DUBEY, J.P. Toxoplasmosis in dogs. Canine Practice, v.28, p.7-28, 1985.

DUBEY, J.P., BEATTLE, C.P. Toxoplasmosis of animals and man. Boca Raton : CRC, 1988. 220p.

DUNCAN, J.R., PRASSE, K.W. Veterinary laboratory medicine - clinical pathology. Iowa : The Iowa State University, 1982. 242p.

GUIMARÃES, A.M., RIBEIRO, M.F.B., LIMA, J.D. Freqüência de anticorpos anti-Toxoplasma em cães de Belo Horizonte, MG. Arquivo Brasileiro de Medicina Veterinária e Zootecnia, v.44, n.1, p.67-68, 1992.

HARTREE, E.F. Determination of protein : A modification of thelowry method that gives a linear photometric response. Analitical Biochemistry, v.48, p.422-427, 1972.

KANEKO, J.J., CORNELIUS, C.E. Clinical biochemistry of domestic animals. San Diego : Academic, 1989. v.2. $352 \mathrm{p}$.

LINDSAY, D.S., DUBEY, J.P., UPTON, S.J., et al. Serological prevalence of Neospora caninum and Toxoplasma gondii in dogs from Kansas. Journal of the_Helminthological Society of Washington, v.57, n.1., p.86-88, 1990. 
NESBIT, J.W., LOURENS, D.C., WILLIAMS, M.C. Spastic paresis in two littermate pups caused by Toxoplasma gondii. Journal South Africa Veterinary Association, v.52, p.243-246, 1981

OPPERMANN, W.H. Versuche zum experimentellen Infection des Hundes mit Toxoplasma - oozysten. Berlin, 1971. 31p. Dissertation (Mestrado em) - Institute Für Parasitologie des Fachbereiches Veterinarmedizin, , Universität Berlin, 1971.

SCHALM, O.W., NEMI, J.C. Veterinary Hematology. 3. ed. Philadelphia : Lea \& Febinger, 1986. 807p.

SHARMA, S.P., GAUTAM, O.P., KHAROLE, M.U. Studies on some aspects of pathogenesis, chemotherapy and serology of experimental toxoplasmosis in dogs. Indian Veterinary Journal, v.50, n.7, p. 623-626, 1973
SUTER, M.M., HAUSER, B., PALMER, D.G., et al. Polymyositis - polyradiculitis due to Toxoplasmosis in the dog: Serology and tissue biopsy as diagnostic aids. Zentralblatt für Veterinärmedizin, v.31, n.10, p.792-798, 1984.

VIDOTTO, O., COSTA, A.J. Toxoplasmose experimental em porcas gestantes. I. Observações clínicas e hematológicas. Arquivo Brasileiro de Medicina Veterinária e Zootecnia, v.39, p.623-639, 1987.

VITOR, R.W.A., PINTO, J.B. Eliminação de Toxoplasma gondii através de urina, saliva e leite de caprinos experimentalmente infectados. Arquivo Brasileiro de Medicina Veterinária e Zootecnia, v.42, n.2, p. 147-154, 1991.

ZAMAN, V. Morfology of Toxoplasma oocysts and its comparison with other cat coccidia. South. Asian Journal Tropical Medicine Public Health, v.1, n.3, p.329-335, 1970

Ciência Rural, v. 31, n. 6, 2001.1043 